Panalungtik: Jurnal yang memuat kajian gagasan dan informasi tentang budaya dan kehidupan masa lalu e-ISSN: 2621-928X

Vol. 1(1) ,Juli 2018, pp 15-26 DOI : https://doi.org/10.24164/pnk.v1i1.4

\title{
SITUS TRADISI BERLANJUT DI BUAHDUA SUMEDANG
}

\section{Tradition Sites Continue in Buahdua Sumedang}

\section{Effie Latifundia dan Sudarti Prijono}

Balai Arkeologi Jawa Barat - Indonesia

Jl. Raya Cinunuk km.17, Cileunyi, Bandung

E-mail: yunda_effie@yahoo.com

Naskah diterima 2 April 2018 - Revisi 25 Juni 2018

Disetujui terbit 27 Juli 2018 - Diterbitkan secara online 31 Juli 2018

\begin{abstract}
The prehistoric tradition that still continues today is the megalithic tradition. Therefore the megalithic tradition is a system of sustainable cultural values or so-called traditions continue. Characteristic of megalithic tradition is ancestor worship or ancestral spirit. Until now, some villages in the area of Buahdua-Sumedang megalithic tradition still continues and can not even be separated from the life of the community supporters. The purpose of this study to explore the sites of tradition continues in the life of the people of Buahdua and surrounding areas even though Islam has grown and embraced. This research is conducted by survey method to collect information and describe the forms of cultural relation with megalithic tradition. The results show that although Islam has grown and adhered to, but the worship of ancestors as local religious understandings before Islam developed still continues. The form of simple ancient tombs with erect stone tombstone, petilasan / tread and even a collection of large stones irregular stone until now still visited for the worshiped or pilgrimage.
\end{abstract}

Keywords: megalithic tradition, tomb, pilgrimage.

\begin{abstract}
Abstrak
Tradisi prasejarah yang masih berlanjut hingga sekarang ini ialah tradisi megalitik. Oleh karenanya tradisi megalitik adalah sistem nilai budaya yang berkelanjutan atau disebut tradisi berlanjut. Ciri khas dari tradisi megalitik ialah pemujaan leluhur atau roh nenek moyang. Hingga sekarang ini, beberapa desa di wilayah Buahdua-Sumedang masih berlangsung tradisi megalitik dan bahkan tidak dapat dipisahkan dari kehidupan masyarakat pendukungnya. Tujuan penelitian ini menggali situs- situs tradisi berlanjut dalam kehidupan masyarakat wilayah Buahdua dan sekitarnya walau Islam sudah berkembang dan dianut. Penelitian ini dilakukan dengan metode survei untuk mengumpulkan informasi dan mendeskripsikan bentuk-bentuk tinggalan budaya hubungannya dengan tradisi megalitik. Hasil penelitian menunjukkan meskipun Islam telah berkembang dan dianut, namun pemujaan terhadap leluhur sebagai paham religi lokal sebelum Islam berkembang masih tetap berlanjut. Bentuk makam kuna sederhana dengan nisan batu tegak, petilasanbatu tegak, petilasan/tapak dan bahkan kumpulan batu-batu alam besar tidak beraturan sampai sekarang masih dikunjungi untuk di dipuja atau diziarah
\end{abstract}

Kata Kunci : tradisi megalitik, makam, ziarah.

\section{PENDAHULUAN}

Geografis kawasan Buahdua merupakan kawasan yang pada masa lampau termasuk ke dalam Kawedanaan Buahdua, dan sekarang sudah mengalami beberapa kali pemekaran. Berlokasi di sebelah utara Kabupaten Sumedang berbatasan langsung dengan Kabupaten Indramayu. tepatnya di sebelah utara Gunung Tampomas. 
Wilayah Kecamatan Buahdua dikelilingi oleh wilayah Kecamatan Surian dan Tanjungkerta di sebelah barat, Kecamatan Cimalaka di sebelah selatan dan Kecamatan Conggeang di sebelah timur. Demikian pula posisi wilayah Sumedang yang strategis, menghubungkan pesisir utara dan pedalaman Jawa Barat, memberikan dugaan bahwa di wilayah ini pada masa lampau pernah dimanfaatkan sebagai jalur masuknya pengaruh budaya dari luar sehingga melahirkan beberapa benda budaya yang merupakan hasil percampuran budaya asli dan pendatang, serta tidak tertutup kemungkinan adanya budaya lama yang masih bertahan yang muncul kembali. Kondisi demikian melahirkan artefak tinggalan budaya baik dalam bentuk struktur permukiman, transportasi, perdagangan, teknologi dan persebaran situs yang beragam.

Dalam studi arkeologi situs tinggalan budaya dapat diklasifikasi, berdasarkan fungsi dan jenis aktivitasnya, seperti situs habitasi, situs perdagangan, situs penjagalan, situs penambangan, situs penguburan, situs seremonial, dan situs perbengkelan (Sharer, 1979: 68-100). Demikian pula persebaran situs-situs apabila dilihat dari aspek keletakannya pada dasarnya juga sangat dipengaruhi oleh perilaku manusia dalam memilih tempat untuk melakukan aktivitas baik sebagai tempat hunian maupun pemujaan sesuai kebutuhan hidupnya. Hal ini juga tidak lepas dari pertimbangan keberadaan sumberdaya alamnya.

Terdapatnya sebaran tinggalan budaya berupa fitur punden dan kubur di wilayah Buahdua yang terletak pada kordinat $06^{\circ} 42^{\prime} 6,72$ ' LS; $107^{\circ} 57^{\prime}$ 13,19" BT dan ketinggian 318 meter di atas permukaan laut (m dpl), pada dasarnya merupakan suatu hasil aktivitas manusia masa lampau. Tinggalan budaya materi berupa sisasisa hasil kegiatan manusia baik yang berupa struktur batu atau lainnya, tetapi diduga sebagai tinggalan budaya adalah merupakan salah satu unsur yang memberikan indikasi adanya aktivitas manusia yang pernah berlangsung di wilayah ini pada masa lampau. Demikian pula sisa-sisa struktur batu di suatu situs memberikan indikasi bahwa di lokasi tersebut pernah berlangsung suatu aktivitas membangun suatu bentuk dengan pola tertentu yang berkaitan dengan fungsi situs. Di wilayah ini berhasil diinventarisir sejumlah situs dengan artefak berbahan batu alam, batu papan (slab), punden, fragmen gerabah dan keramik.

Demikian halnya sebagian besar penempatan situs-situs tinggalan budaya di tempatkan pada lahan yang tinggi dan jauh dari pemukiman. Tradisi yang berasal dari masa pra Islam ini terus berlanjut sampai sekarang. Apabila pernyataan tersebut dikaitkan dengan pendapat Sukendar, bahwa tempat yang tinggi merupakan tempat bersemayam arwah nenek moyang berkaitan dengan kepercayaan yang telah ada sejak pra-Islam (Sukendar, 1981: 85). Alasan lain pemilihan lokasi bangunan makam di gunung atau bukit ini tampaknya juga atas pertimbangan kesakralan tanahnya (Mustopo, 2001: 185). Berdasarkan kenyataan tersebut, permasalahan yang 
diangkat pada tulisan ini adalah, untuk mengungkap situs-situs tradisi megalitik yang masih berlangsung hingga sekarang ini yang berhubungan dengan konsepsi religi. Penelitian ini bertujuan menggali sisa-sisa tradisi berlanjut dalam kehidupan masyarakat walau Islam sudah berkembang dan dianut oleh masyarakatnya pendukungnya.

Pembahasan pada penelitian menggunakan metode penelitian kualitatif, sehingga survei dilakukan untuk memperoleh data dan mengetahui keadaan objek secara langsung, kemudian diperoleh data yang dapat dianalisis untuk mengetahui perpaduan budaya yang terdapat pada situs-situs arkeologi tersebut. Pengumpulan data dilakukan di wilayah Buahdua dan sekitarnya. Interpretasi dilakukan dengan mengintegrasikan bentukbentuk nisan dengan hasil wawancara dan studi pustaka yang berkaitan dengan sejarah Islamisasi dan tradisitradisi lokal yang berkembang di wilayah penelitian.

\section{HASIL DAN PEMBAHASAN}

$\begin{array}{ll}\text { Situs-Situs } & \text { Bercorak Tradisi } \\ \text { Megalitik } & \end{array}$

Tinggalan budaya materi berupa artefak atau fitur merupakan suatu indikasi adanya aktivitas manusia yang pernah berlangsung di suatu lokasi. Demikian pula adanya batu datar, batu berdiri, fitur struktur batu dengan batu tegak atau menhir merupakan indikasi adanya pemanfaatan sumberdaya alam yang pernah digunakan untuk kegiatan budaya, baik yang bersifat profan atau sakral. Hal ini memberikan gambaran bahwa pada masa lampau wilayah Buahdua dan sekitarnya pernah dimanfaatkan oleh sekelompok masyarakat pendukung budaya tradisi megalitik tempat melakukan aktivitas ritual. Pemilihan lokasi Buahdua sebagai tempat beraktivitas, tentunya didasari oleh berbagai pertimbangan seperti letak yang strategis dan keadaan alam yang memungkinkan, misalnya dekat dengan sumber air, dikelilingi perbukitan sebagai pertahanan dan tanah yang subur. Walaupun Islam masuk dan berkembang, tetapi anasir-anasir budaya lokal tidak hilang begitu saja dalam kehidupan masyarakat di wilayah tersebut. Hingga sekarang ini, sebagian masyarakat masih mempertahankan tradisi megalitik pada beberapa situs makam kuna. Berdasarkan informasi penduduk situs-situs makam atau kubur di kawasan Buahdua dan sekitarnya masih menggunakan nisan batu tegak merupakan salah satu bentuk kontinuitas tradisi megalitik.

Situs pertama di wilayah Buahdua adalah Situs Haur Koneng berada di Blok Haur Kuning, Dusun Curug, Desa Hariang. Masyarakat menamakan makam Eyang Dalam Suryawetcana berasal dari Cirebon.

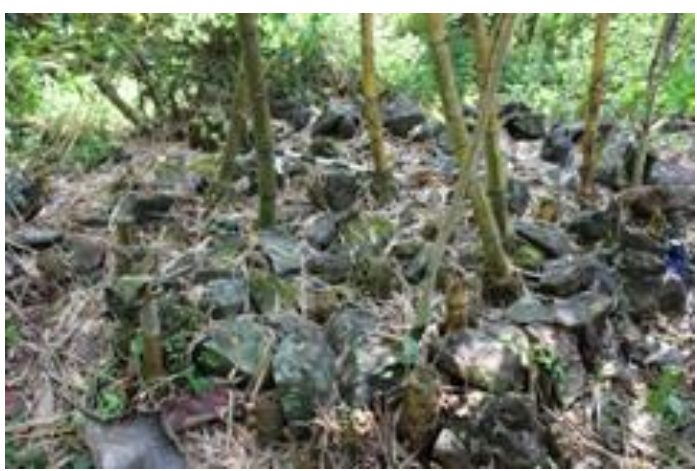

Gambar 1. Makam Eyang Dalam Suryawetcana (Sumber: Dokumen Balai Arkeologi Jawa Barat, 2015) 
Unsur megalitik terlihat pada jirat makam yang terbuat dari susunan batubatu gunung berbentuk melingkar ditandai dua nisan batu tegak di atasnya. Di tengah-tengah makam ditumbuhi pohon haur kuning menurut cerita Rahtim (51 tahun), bahwa pada awalnya adalah tongkat Eyang Dalam Suryawetcana yang ditancapkan dan akhirnya tumbuh pohon haur kuning. Luas areal makam $280 \mathrm{~cm} \times 330 \mathrm{~cm}$ berada di tanah milik desa. Makam terlihat sering dikunjungi para peziarah dari masyarakat sekitar dan terletak jauh dari pemukiman penduduk.

Situs kedua di kawasan Buahdua adalah situs Gunung Harendong. Masyarakat menamakan makam Eyang Suryaatmaja atau nama lain Pangeran Mekah karena beliau wafat di Mekkah dan ini merupakan petilasan. Makam terletak di bawah pohon beringin diberi cungkup serta dikelilingi pagar bambu. Makam berada di perbukitan, dengan keletakan berada pada ketinggian 300 mdpl. Jirat makam sudah diperbaharui diganti keramik dengan nisan asli berupa batu tegak berbentuk pipih. Luas areal makam $530 \mathrm{~cm}$ x $950 \mathrm{~cm}$. Makam sering dikunjungi peziarah terutama pada malam senin dan malam jumat

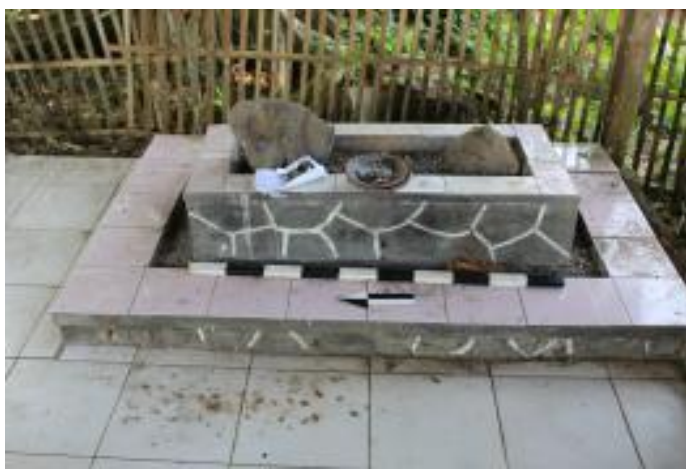

Gambar 2. Petilasan Eyang

Suryaatmaja/Pangeran Mekah (Sumber:

Dokumen Balai Arkeologi Jawa Barat, 2015) dengan maksud dan tujuan untuk masa depan lebih baik.

Kemudian situs ketiga yaitu Situs Hariang. Situs ini ditandai dengan

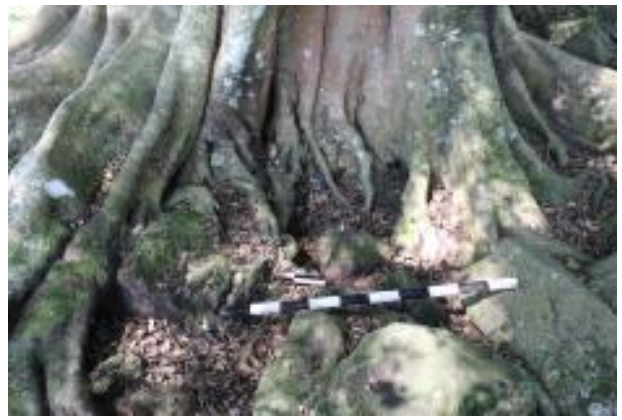

Gambar 3. Makam Eyang Guriang (Sumber: Dokumen Balai Arkeologi Jawa Barat, 2015)

tumpukan batu alam di bawah pohon beringin. Situs terletak di dekat aliran sungai Hariang. Situs berada di tanah milik desa dekat dengan lahan persawahan penduduk. Masyarakat menamakan makam Eyang Guriang dan dikeramatkan. Di makam tersebut ditemukan bekas-bekas sesaji yang dibawa oleh peziarah yang datang dari luar kota di antaranya dari Bandung, Jakarta, Cirebon. Pada bulan Maulud makam Eyang Guriang banyak dikunjungi peziarah dengan maksud dan tujuan untuk memohon hidup yang lebih baik.

Berikutnya Situs Astana Tengah berada di Blok Astana Tengah, Dusun Hariang, Desa Hariang. Ciri dari tradisi megalitik situs Astana Tengah yakni pada makam di tandai dua nisan batu tegak yang berorientasi timur-Barat. Nisan bagian timur bahan batu alam yang berbentuk empat persegi berukuran tinggi $32 \mathrm{~cm}$, lebar $22 \mathrm{~cm}$, tebal $8 \mathrm{~cm}$, sedangkan nisan bagian barat bahan dari batu alam berbentuk pipih berukuran tinggi $49 \mathrm{~cm}$, lebar $15 \mathrm{~cm}$, tebal $8 \mathrm{~cm}$. Sementara makam berada di 
gundukan tanah kering tanpa jirat yang dikelilingi sawah penduduk. Masyarakat menamakan makam Buyut Siluman dan dikeramatkan.

Selanjutnya Situs Candikarang berada di Blok Candikarang, Dusun Cilumping, Desa Cikurubuk, Kecamatan Buahdua. Lahan situs merupakan perbukitan berada pada

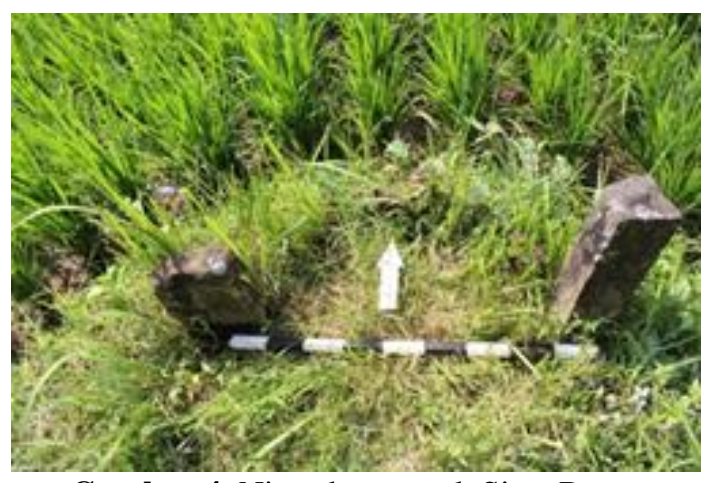

Gambar 4. Nisan batu tegak Situs Buyut Siluman (Astana Tengah) (Sumber: Dokumen Balai Arkeologi Jawa Barat, 2015)

ketinggian $717 \mathrm{~m}$ dpl. Di sebelah timur laut dari bukit ini mengalir Ci Logang yang bermuara $\mathrm{ke} \mathrm{Ci}$ Jurai yang merupakan anak $\mathrm{Ci}$ Kandung dan sungai ini bermuara ke $\mathrm{Ci}$ Manuk di Indramayu. Ci Logang merupakan batas alam dari Desa Bojongloa dan Desa Cikurubuk.

Di areal lahan ditemukan tinggalan budaya berupa struktur menyerupai makam atau kubur dengan nisan terdiri dari batu menhir baik nisan kepala maupun nisan kaki. Nisan kepala merupakan nisan menhir berbentuk pipih terbuat dari sejenis batu atau karst gunung, sedangkan nisan kaki tersusun dari nisan menhir berbentuk silindrik. Menurut informasi Wiria (63) ini bukan makam akan tetapi petilasan dahulu tempat berkumpulnya para leluhur Sumedang dalam strategi menyebarkan
Islam. Di permukaan areal situs juga banyak sebaran fragmen tembikar polos dengan teknik pijit dan tembikar hias garis-garis namun sudah sangat aus, elain itu ditemukan sebaran keramik Cina.

Selanjutnya, situs berada di Blok Ciembutan, Dusun Cilumping, Desa Cikarubuk, terletak di lereng perbukitan jauh dari pemukiman penduduk. Situs ditandai makam atau kubur tua dan masyarakat menyebutnya makam Sanghyang Ciembutan atau Prabu Daniswara. Informasi dari Wiria (63 th) awalnya kubur tersebut merupakan batu tegak, namun kemudian direnovasi oleh masyarakat pendukungnya menjadi berjirat dengan dua nisan di atasnya. Sementara sekitar $200 \mathrm{~m}$ ke arah tenggara dari kubur ini terdapat mata air alam Ciembutan yang sangat besar debitnya. Di permukaan Ciembutan terdapat batu alam dengan permukaan datar digunakan sebagai tempat menaruh sesaji.

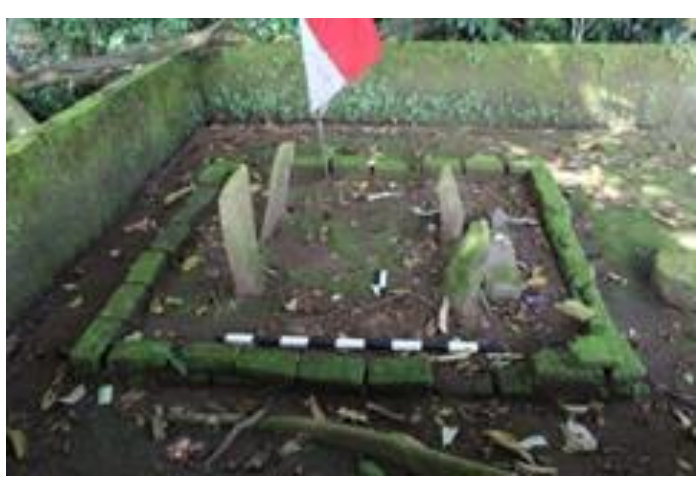

Gambar 5. Situs Candikarang, Desa Cikarubuk, Kecamatan Buahdua (Sumber: Dokumen Balai Arkeologi Jawa Barat, 2015)

Survei dilanjutkan di Situs Malandang, terletak komplek makam yang dikenal sebagai makam Malandang. Di komplek makam ini terdapat 4 makam/kubur yang ditandai dengan nisan batu alam tanpa jirat dan 
masing-masing diberi nama sebagai Eyang Wirakusuma, Eyang Wirakutamaya, Eyang Agus Salam, dan Eyang Siti Candra Komalasari. Keempat orang ini berasal dari Cirebon. Menurut Memet Kusnadi (71) juru kunci makam, Situs Malandang adalah makam leluhur Kampung Malandang. Lahan makam ini mempunyai luas 500 bata. Di areal situs terdapat pohonpohon tua yang tidak diperbolehkan untuk diambil oleh masyarakat umum maupun keturunan karuhun sendiri. Di areal situs terdapat dua kelompok makam; kelompok pertama dikelilingi pagar besi dan mempunyai luas 5 x 10 $\mathrm{m}$, terletak di bagian barat dan merupakan makam dari Agus Salam, Eyang Wirakusuma, Eyang Wirakutamaya. 1) Makam Agus Salam. Makam ini ditandai 3 batu alam dengan bentuk tidak beraturan berorientasi utara-selatan. Batu tegak bagian utara berukuran tinggi $36 \mathrm{~cm}$, lebar $25 \mathrm{~cm}$ dan tebal $9 \mathrm{~cm}$. Batu bentuk bulat di bagian selatan berukuran panjang $40 \mathrm{~cm}$, lebar $30 \mathrm{~cm}$ dan tinggi $20 \mathrm{~cm}$, dengan jarak antar nisan $90 \mathrm{~cm}$. Makam Agus Salam tidak berjirat terletak di bawah pohon kemuning. 2) Makam Eyang Wirakusuma, terletak $267 \mathrm{~cm}$ ke arah barat dari makam Agus Salam, di tandai dengan satu batu tegak terletak di bagian utara, berukuran tinggi $22 \mathrm{~cm}$, lebar $11 \mathrm{~cm}$, dan tebal $10 \mathrm{~cm}$, dan makam tidak berjirat, dan 3) Makam Eyang Wirakutamaya, berada $83 \mathrm{~cm}$ ke arah barat dari makam Eyang Wirakusuma. Makam tidak berjirat ditandai 2 nisan batu tegak berorientasi utara-selatan. Nisan bagian utara berukuran tinggi $21 \mathrm{~cm}$, lebar $11 \mathrm{~cm}$ dan tebal $11 \mathrm{~cm}$, sedangkan nisan

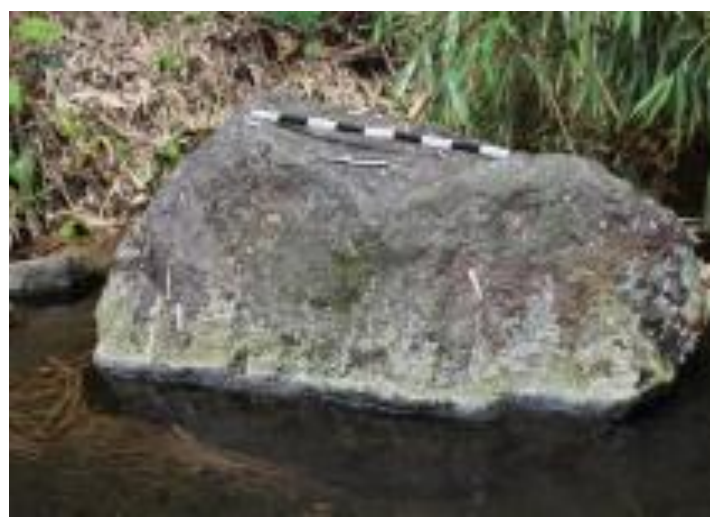

Gambar 6. Batu Alam dengan permukaan datar dekat mata air Ciembutan (Sumber: Dokumen Balai Arkeologi Jawa Barat, 2015)

bagian selatan kondisi rebah berukuran anjang $28 \mathrm{~cm}$, lebar $20 \mathrm{~cm}$ dan tebal 12 $\mathrm{cm}$, dengan jarak nisan $70 \mathrm{~cm}$.

Sementara pada jarak $45 \mathrm{~m}$ ke arah barat dari komplek makam Agus Salam terletak makam Eyang Ratu Siti Candra Komalasari dikelilingi oleh pagar bambu. Makam menyerupai kubur batu berbentuk empat persegi yang merupakan susunan batu-batu papan (slab) atau masyarakat menyebut sebagai batu balai/rubak/tatapakan atau lempengan batu/slab. Kubur tersebut berukuran panjang $180 \mathrm{~cm}$ dan lebar $114 \mathrm{~cm}$, dan kubur ini dikelilingi pagar bambu berukuran 3 x $3 \mathrm{~m}$. Selanjutnya sekitar $7 \mathrm{~m}$ ke arah selatan dari kubur Agus Salam terdapat dua batu besar berdampingan pada jarak $130 \mathrm{~cm}$, dikenal sebagai pintu gerbang masuk ke komplek kubur. Di sebelah timur lahan komplek makam ini terdapat Ci Porong yang merupakan batas dengan Desa Gandereh. Semua makam di kompleks tersebut dikeramatkan oleh masyarakat setempat dan sering dikunjungi peziarah dengan membawa sesaji. 
Masih di wilayah Buahdua ditemukan Situs Barujul berada di Dusun Barujul, Desa Gandereh. Masyarakat menamakan makam Buyut tinggi $30 \mathrm{~cm}$, lebar $12 \mathrm{~cm}$ dan pada jarak $50 \mathrm{~cm}$ ke utara terdapat batu datar berukuran diameter $25 \mathrm{~cm}$ dan tebal 6 $\mathrm{cm}$.

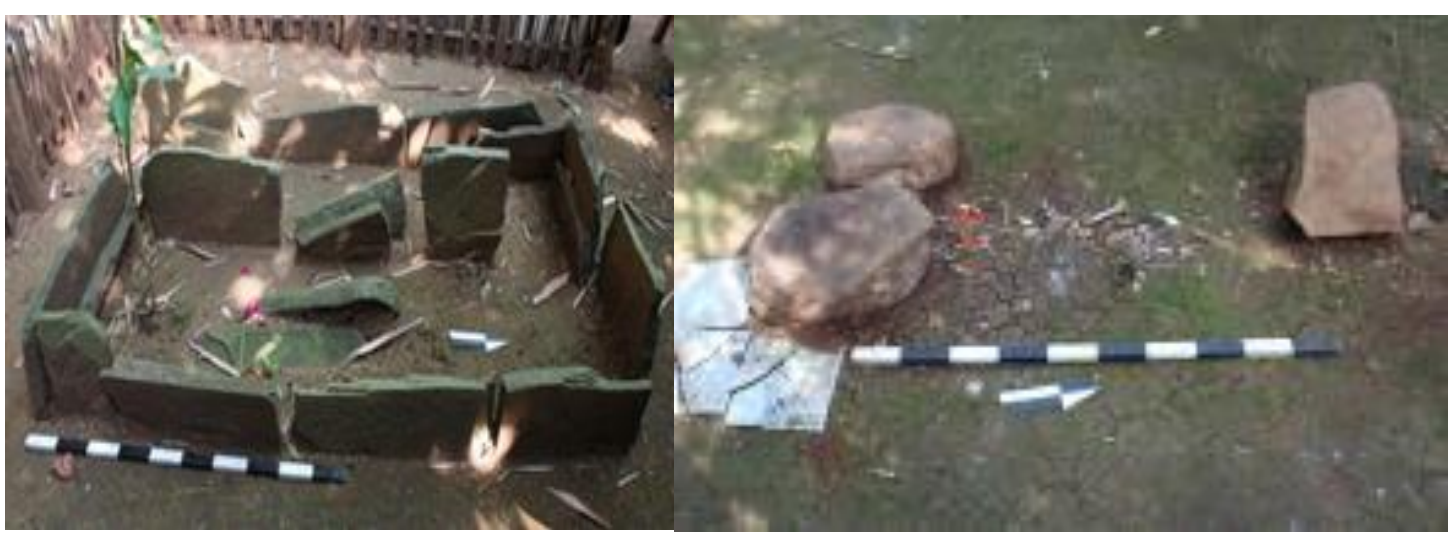

Gambar 7. Kubur batu papan dan Makam Agus Salam di kompleks Situs Maladang (Sumber: Dokumen Balai Arkeologi Jawa Barat, 2015)

Burujul atau Eyang Kumis. Makam dikeramatkan dan sering dikunjungi peziarah. Di komplek makam ini terdapat dua kelompok batu yang disusun memanjang utara-selatan tanpa jirat. Area komplek kubur ini dibatasi oleh dinding susunan batu berbentuk persegi empat dengan ukuran $8,30 \mathrm{x}$ 4,70 $\mathrm{m}$ dan yang masih tersisa di bagian sebelah timur dan selatan dengan tinggi 60-80 $\mathrm{cm}$. Area dibagi menjadi dua bagian timur dan barat yang dibatasi oleh susunan batu alam jarak antara kumpulan batu sebelah barat dan timur 5,36 m. Kelompok susunan batu sebelah timur berukuran panjang $160 \mathrm{~cm}$ dengan dua nisan batu alam posisi rebah, batu sebelah utara berukuran panjang $54 \mathrm{~cm}$, lebar $14 \mathrm{~cm}$, sedangkan nisan batu tegak bagian selatan berukuran tinggi $36 \mathrm{~cm}$, lebar $13 \mathrm{~cm}$ dan tebal $28 \mathrm{~cm}$, dengan jarak antar nisan $110 \mathrm{~cm}$. Sedangkan kelompok batu sebelah barat berukuran panjang $100 \mathrm{~cm}$ dipermukan ditandai dengan batu tegak di sebelah selatan berukuran
Survei dan deskripsi juga diarahkan pada situs Hariang Tonggoh, di Dusun Hariang Tonggoh, Desa Boros, Kecamatan Tanjungkerta. Masyarakat menamakan makam Buyut Enden dan dikeramatkan. Situs ditandai oleh tatanan batu-batu alam pipih dan batu tegak. Fitur tatanan batu ini terletak di tanah desa yang merupakan tempat pemakaman umum Dusun Hariang Tonggoh. Situs dikelilingi pagar bambu dengan luas areal kubur 13 x $9 \mathrm{~m}$. Permukaan areal situs ini terbagi menjadi 3 bidang persegi empat yang memanjang dari tenggara-barat laut. Kubur Buyut Enden terletak di sebelah tenggara yang ditandai dengan dua batu tegak berjajar arah tenggarabarat laut, dan hamparan tatanan batu papan $(s l a b)$. Bentuk persegi empat ini berukuran 2,7 x 3,10 m. Di sebelah barat laut terdapat persegi empat yang berukuran 3,20 x 3,10 m, dan terletak kubur suaminya bernama Uyut Ulis yang ditandai satu batu tegak, sedangkan persegiempat yang di bagian 
tengah berukuran $1,30 \times 3,10$ m serta di bagian pojok barat daya terdapat tumpukan batu yang disusun melingkar. Situs ini masih sering dikunjungi peziarah dengan tujuan dan maksud kehidupan lebih baik.

Masih di kawasan Tanjungkerta terdapat situs Gunung Datar berada di Dusun Gunung Datar, Desa Gunung Datar, dan terletak di areal pemakaman umum desa. Masyarakat menamakan makam Buyut Entin dan masih sering dikunjungi peziarah. Kubur ditandai

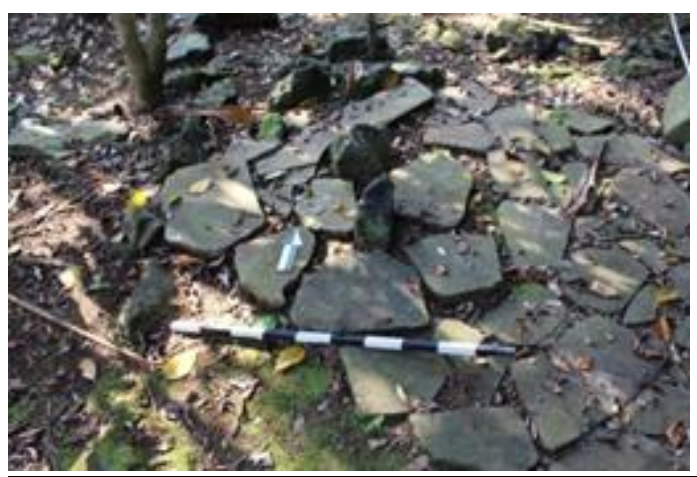

Gambar 8. Makam Buyut Enden di situs

Hariang Tonggoh. (Sumber: Dokumen Balai Arkeologi Jawa Barat, 2015)

dengan dua nisan tegak tidak beraturan, serta jirat persegiempat dari tatanan batu alam. Nisan sebelah utara berukuran tinggi $45 \mathrm{~cm}$, panjang $67 \mathrm{~cm}$, lebar $35 \mathrm{~cm}$, sedangkan nisan sebelah selatan berukuran tinggi $38 \mathrm{~cm}$, panjang $60 \mathrm{~cm}$, dan lebar $27 \mathrm{~cm}$. Tidak banyak diketahui tokoh tersebut menurut Yatie Turyati (65 tahun) beliau terkenal dengan kesaktiannya dan sampai saat ini sering dikunjungi peziarah yang datang dari Cirebon, Jawa, Banten, Ciamis.

Selain situs Gunung Datar, terdapat pula situs Cipela terletak di Dusun Cipela, Desa Tanjungmekar. Menurut informasi Emak Ntar (56), makam di situs ini merupakan makam Eyang Haji Pangencar berasal dari Cirebon. Makam ditandai tumpukan batu-batu alam tidak bernisan. Jirat berukuran panjang $350 \mathrm{~cm}$, dan lebar $230 \mathrm{~cm}$. Lebih kurang $140 \mathrm{~cm}$ arah

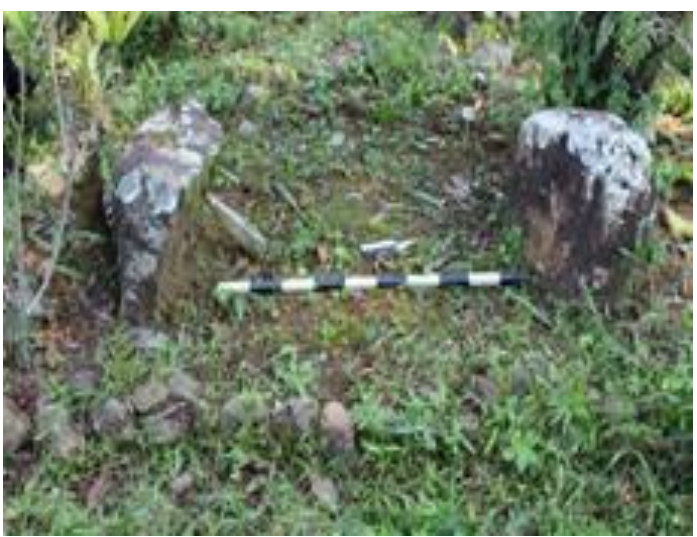

Gambar 9. Nisan Batu tegak Makam Buyut Entin di situs Gunung Datar (Sumber: Dokumen Balai Arkeologi Jawa Barat, 2015)

barat dari makam Eyang Haji terdapat makam istrinya bernama Eyang Siti Dewi.

Survei dan deskripsi juga diarahkan pada Situs Cieunteung berada di lahan pemakaman umum di tanah desa di Blok Cipamekar, Desa Cipamekar, Kecamatan Conggeang. Masyarakat menamakan makam Dalem

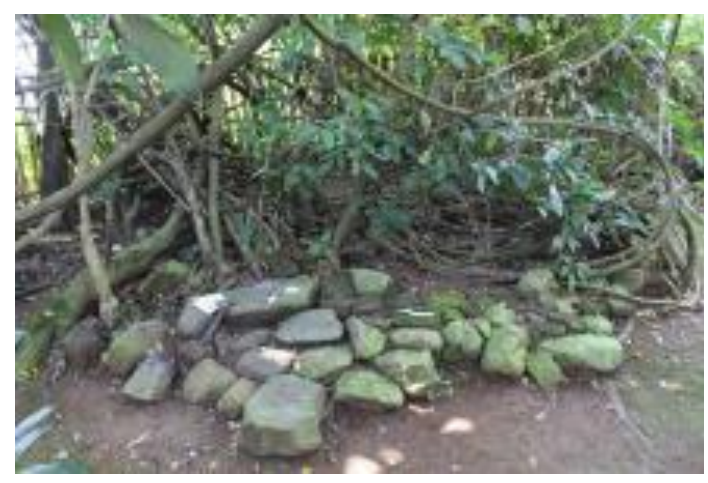

Gambar 10. Makam Eyang Haji Pangencar Cipela (Sumber: Dokumen Balai Arkeologi Jawa Barat, 2015)

Tumenggung Surabima dan dikeramatkan. Ditandai dengan punden yang terdiri dari empat teras berundak, 
berupa fitur kubur dari susunan batu papan (slab). Di teras teratas (4) terletak kubur yang tertutup oleh susunan batu papan dengan batu tegak di sisi bagian utara berukuran tinggi $44 \mathrm{~cm}$, lebar 11 $\mathrm{cm}$, tebal $14 \mathrm{~cm}$ dan nisan selatan berukuran tinggi $25 \mathrm{~cm}$, lebar $11 \mathrm{~cm}$ dan tebal $8 \mathrm{~cm}$. Jirat berukuran panjang $280 \mathrm{~cm}$ dan lebar $170 \mathrm{~cm}$. Luas areal makam 9 x $8 \mathrm{~m}$ berbentuk persegi empat dengan tangga naik di bagian

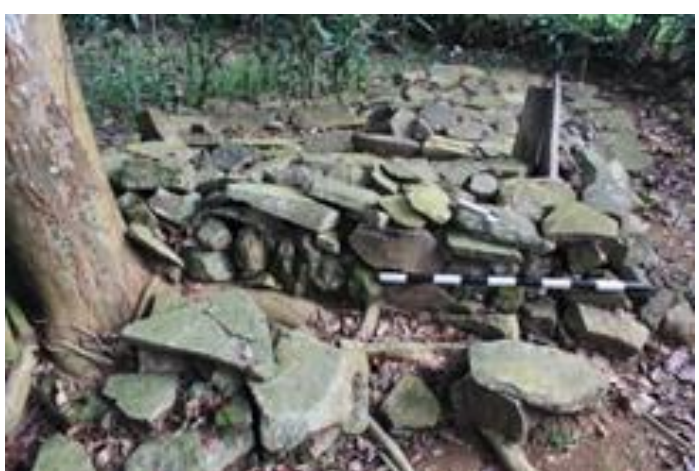

Gambar 11. Makam Dalem Tumenggung Surabima (Sumber: Dokumen Balai Arkeologi Jawa Barat. 2015)

pojok tenggara. Tangga naik terdiri dari 4 anak tangga, tangga pertama tinggi 43 $\mathrm{cm}$, tangga kedua tinggi $22 \mathrm{~cm}$, tangga ke tiga tinggi $20 \mathrm{~cm}$, dan tangga ke empat tinggi $15 \mathrm{~cm}$.

Berikutnya survei di Kecamatan Tanjung Medar tepatnya di Blok Medang, Dusun Cisae, Desa Jingkang terdapat Situs Medang. Situs berada di puncak bukit jauh dari pemukiman penduduk berada pada ketinggian 644 mdpl. Tinggalan budaya yang terdapat
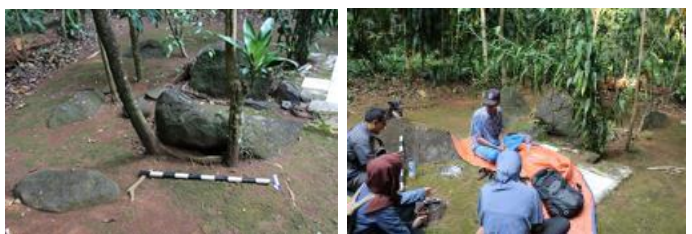

Gambar 12. Situs Medang

(Sumber: Dokumen Balai Arkeologi Jawa Barat, 2015) di situs ini berupa sebaran struktur batu alam dengan areal situs luas 70 x $60 \mathrm{~m}$.

Situs ditandai kumpulan batubatu alam besar tidak beraturan, dan tampaknya batu-batu tersebut dimanfaatkan untuk pemujaan. Menurut Oyo Suryani (81 tahun) bahwa situs tersebut yang disebut Sumedang.

Batu-batu alam yang berkelompok tersebut masing-masing mempunyai nama sebagai: Embah Mangkunegara, Prabu Siliwangi, Embah Waris, Kanjeng Dalem, Uyut Sempreng, dan Eyang Zaenem. Kemudian lebih kurang $20 \mathrm{~m}$ ke arah tenggara situs Medang terdapat makam Embah Jaya Perkosa.

\section{Situs-Situs Buah Dua Sebagai Sarana Pemujaan}

Di beberapa wilayah Nusantara kelangsungan tradisi megalitik terus berlanjut dan dipertahankan oleh masyarakat pendukungnya, walau masa prasejarah sudah berakhir. Perkembangan tradisi ini, berlangsung cukup lama yaitu dari masa neolitik hingga sekarang (Van Heekeren, 1958: 44). Unsur tradisi prasejarah atau pra Islam terlihat dalam sistem kepercayaan yaitu pemujaan terhadap arwah para leluhur. Di Indonesia tradisi dan ritual tersebut biasanya dilakukan masyarakat dalam pemakaman dan penguburan. Kebiasaan tersebut menggambarkan religi sebagai tradisi yang berlanjut yang terus hidup dan berlangsung di tengah-tengah kehidupan beberapa kelompok masyarakat di Indonesia. Menurut Prasetyo, apabila manusia tidak mampu menghadapi masalah yang menggelisahkan, maka untuk 
mengatasinya dengan memanipulasi makhluk dan kekuatan supernatural. Hal ini jelas bahwa agama atau religi dipandang sebagai kepercayaan dan pola perilaku digunakan manusia untuk mengendalikan aspek alam semesta yang tidak dapat dikendalikannya. Manusia meminta bantuan pada dunia supernatural dilakukan melalui doa, sesajian dan kegiatan ritual umum (Prasetyo, 2004: 161).

Makam dalam tradisi megalitik biasanya diwujudkan dalam bentuk sederhana. Demikian halnya makammakam keramat yang tersebar di wilayah Buahdua dan sekitarnya hanya berupa susunan batu dengan nisan-nisan batu tegak/menhir berukuran sedang dan kecil, dengan bentuk persegi panjang, pipih, bulat, lonjong atau tidak berbentuk. Di wilayah Buahdua dan sekitarnya meskipun Islam terus berkembang, namun budaya lokal yang cenderung megalithis terus berlangsung dan mungkin tak bisa dihilangkan begitu saja dalam kehidupan oleh pendukungnya. Dalam kehidupan masyarakat makam-makam kuna tersebut dikeramatkan dan disucikan, bahkan kadang secara keliru dijadikan sebagai tempat meminta suatu keberkahan. Pengkeramatan makam, merupakan tradisi sebagian besar masyarakat muslim di wilayah Nusantara, terutama di Jawa. Aktivitas mengunjungi makam atau ziarah merupakan bentuk perkembangan dari budaya megalitik yang berkembang pada masa prasejarah Ambary (1998: 43).

Makam dalam tradisi megalitik biasanya diwujudkan dalam bentuk sederhana. Demikian halnya makammakam keramat yang tersebar di wilayah Buahdua dan sekitarnya hanya berupa susunan batu dengan nisan-nisan batu tegak/menhir berukuran sedang dan kecil, dengan bentuk persegi panjang, pipih, bulat, lonjong atau tidak berbentuk. Menurut Sukendar (1983), menhir merupakan tinggalan tradisi megalitik yang sangat banyak ditemukan diberbagai situs dan berbagai masa setelah periode Neolitik, yang terus berkembang hingga masa pengaruh Hindu, Islam bahkan hingga masa sekarang (Sukendar, 1983:93). Menhir atau batu tegak, menurut Sukendar (1983) secara umum mempunyai tiga fungsi: yaitu batu tegak yang berfungsi dalam upacara penguburan, upacara pemujaan dan batu tegak yang tidak berfungsi religius (Sukendar, 1983: 100). Menurut Kartodirjo (1975) yang dikutip Wuri Handoko, menjelaskan bahwa menhir dalam alam kepercayaan masyarakat megalitik berfungsi sebagai medium penghormatan, menjadi tahta kedatangan roh, sekaligus lambang dari orang-orang yang diperingati. Dengan demikian kontinuitas tradisi megalitik yakni penggunaan menhir sebagai nisan kubur, menandai karakteristik Islam yang sangat akomodatif terhadap paham-paham lokal yang merupakan bentuk kepercayaan terhadap leluhur yang diwarisi sejak zaman megalitik dan terus bertahan hingga persentuhannya dengan Islam (Handoko, 2014: 37). Sedangkan pendapat Wiyana, bahwa pemberian tanda berupa menhir pada masa prasejarah dan nisan pada masa 
Islam, secara prinsip mempunyai kesamaan, yaitu sebagai tanda adanya penguburan (Wiyana, 2008: 311).

Kebiasaan lain yang masih terus berlanjut hingga sekarang oleh sebagian masyarakat wilayah Buahdua dan sekitarnya ternyata tidak hanya mendatangi atau menziarahi makammakam keramat, namun petilasanpetilasan atau tapak-tapak yang bukan makam juga dikunjungi untuk diziarah. Salah satu petilasan dibentuk seperti makam dilengkapi dengan jirat dan dua nisan batu tegak, yaitu situs Gunung Harendong. Masyarakat menamakan makam Eyang Suryaatmaja atau Pangeran Mekah karena beliau wafat di Mekkah. Sampai sekarang masih dikunjungi untuk diziarah dengan membawa sesaji berupa rokok, kemenyan, kopi dan lainnya. Demikian pula situs berupa kumpulan batu-batu alam letaknya berada di puncak bukit yang jauh dari pemukiman penduduk oleh pendukungnya dimanfaatkan untuk pemujaan. Situs tersebut adalah situs Medang yang terletak di Desa Jingkang, Kecamatan Tanjung Medar. Situs Medang ditandai kumpulan batu-batu alam besar dan kecil dengan bentuk tidak beraturan terletak pada ketinggian $644 \mathrm{~m}$ dpl. Batu-batu alam yang berkelompok tersebut oleh masyarakat pendukungnya masing-masing diberi nama sebagai Embah Mangkunegara, Prabu Siliwangi, Embah Waris, Kanjeng Dalem, Uyut Sempreng, dan Eyang Zaenem, sampai sekarang dikunjungi untuk maksud dan tujuan tertentu dengan membawa sesaji yang dipimpin oleh juru kunci situs.

Bukti-bukti arkeologis di wilayah Buahdua menunjukkan bahwa masyarakat di satu pihak telah mendapat pengaruh budaya Islam, namun secara fisikal masih memperlihatkan dominasi unsur budaya lokal, yakni memperlihatkan kesinambungan dengan anasir budaya Pra Islam, yang oleh Ambary (1986; 1991) dikutip oleh Handoko disebut sebagai permanensi etnologis (Handoko, 2014: 43). Bahkan kemungkinan berkembangnya Islam di wilayah Buahdua dan sekitarnya masa itu berjalan lamban karena faktor lingkungan alam. Lokasi desa-desa wilayah Buahdua dan sekitarnya hingga sekarang terletak di perbatasan, pedalaman, perbukitan, dan kawasan terpencil, sehingga kurang mendapat pengaruh atau kontak budaya luar yang lebih terbuka. Hal- hal tersebut dapat mengakibatkan unsur lokal semakin kuat/dominan mengakar dalam tata laku dan kepercayaan lama (penghormatan terhadap arwah leluhur) yang dianut, karena masyarakat prasejarah lebih banyak mempengaruhinya dengan pola pikir sederhana. Dengan demikian menggambarkan bahwa meskipun Islam telah dianut namun budaya lokal yang cenderung megalithis sulit atau bahkan mungkin tak bisa dihilangkan.

\section{PENUTUP}

Penelitian arkeologi di beberapa desa wilayah Buahdua dan sekitarnya Kabupaten Sumedang dapat menggambarkan bagaimana dinamika budaya sebagian masyarakatnya yang masih berpegang teguh pada kepercayaan leluhur. Keyakinan dalam hidupnya diwujudkan dengan tindakan berkunjung ke tempat yang dianggap 
keramat. Pemujaan terhadap leluhur atau arwah nenek moyang, tampaknya merupakan kepercayaan masih sangat kuat dan terus berlanjut meskipun Islam telah berkembang dan dianut. Masih hidupnya unsur-unsur lokal, yaitu tradisi praIslam hal ini menunjukkan adanya kompromi kultural. Fenomena pola keletakan situs di perbukitan, penempatan situs jauh dari pemukiman penduduk, penanda makam nisan batu tegak, dan ziarah makam, hal ini menunjukkan kehidupan religi tradisi megalitik yang terus berlanjut. Selain itu, terlihat adanya kesejajaran makna dan fungsi petilasan/tapak bukan makam dengan bangunan makam yang sebenarnya. Ke tempat-tempat tersebut sering didatangi masyarakat pendukungnya dengan berbagai maksud dan tujuan dengan membawa sesaji. Selain itu, pemujaan masih dilakukan pada situs berupa kumpulan batu-batu alam, masing-masing diberi nama sebagai media lambang dari leluhur oleh masyarakat pendukungnya.

Melalui penelitian arkeologi akhirnya dapat mengungkap sejarah budaya masyarakat di wilayah Buahdua dan sekitarnya pada masa lalu dan sekarang, bahwa Islam berakulturasi dengan kepercayaan terhadap arwah leluhur. Meskipun Islam telah dianut sebagai agama, namun kepercayaan terhadap leluhur masih terus berlanjut dan tetap dipertahankan oleh masyarakat pendukungnya.

\section{DAFTAR PUSTAKA}

Ambary, Hasan Muarif. 1998. Menemukan Peradaban, Jejak Arkeologis dan Historis Islam Indonesia. Jakarta: Logos Wacana Ilmu.

Handoko, Wuri. 2014. Tradisi Nisan Menhir pada Makam Kuno Raja-Raja di Wilayah Kerajaan Hitu. Kapata Arkeologi 10 (1): 33-46.

Heekeren, H.R.Van. 1958. The Bronze Iron Age of Indoneisa, VKI XXII. s'Gravenhage: Martinus Nijhoff.

Mustopo, Moehammad Habib. 2001. Kebudayaan Islam di Jawa Timur Kajian Beberapa Unsur Budaya Masa Peralihan. Yogyakarta: Jendela Grafika.

Prasetyo, Bagyo, dkk. 2004. Religi Pada Masyarakat Prasejarah Di Indonesia. Jakarta: Pusat Penelitian Arkeologi Nasional.

Sharer, Robert.J 7 Wendy Ashmore.1979. Fundamental of Archeology. Menlo Park, California: The Benyamin/Cummings Publishing Company, Inc.

Sukendar, Haris. 1981. Peninggalan Tradisi megalitik di daerah Cianjur, Jawa Barat. Jakarta: Pusat Penelitian Arkeologi Nasional.

Wiyana, Budi. 2008. Dari Menhir ke Nisan: Suatu Dinamika Budaya. Kumpulan Makalah Pertemuan Ilmiah Arkeologi. Kediri, 23-28 Juli 2002. Jakarta: Ikatan Ahli Arkeologi Indonesia. 